\title{
A Study on Prevalence of Ovine Fasciolosis in Busa Town, Dawo Woreda, South West Shoa Zone, Oromia Region
}

\author{
Mukarim Abdurahaman,Tamirat Dinagde, Teha Kedir,Tajudin Ahimad,Tahir Said, Teriku \\ Mamo, Haregawi Tesfaye \\ Jimma University College of Agriculture and Veterinary Medicine, (JUCAVM), Ethiopia
}

*Corresponding Author: Mukarim Abdurahaman, Jimma University College of Agriculture and Veterinary Medicine, (JUCAVM), Ethiopia

\begin{abstract}
A cross-sectional study was conducted from June 2018 to November 2018 to determine the prevalence of ovine fasciolosis in Oromia region, South West Shoa, 285 fecal samples were randomly collected directly from the rectum of individual animals. Parasitological investigation was performed using sedimentation technique. From 285 coprologically examined sheep, 150 animals found positive for fasciolosis with an overall prevalence of 52.63\%. Difference in prevalence rate observed among the three study sites from which the samples were collected. Hence, the prevalence rates recorded were $46.6 \%$ in Qarsa Galute $23.3 \%$ in Qarsabonbi and 30\% BurqaGode. The difference in the prevalence in the three study sites was not statistically significant $(p>0.05)$. The prevalence of ovine fasciolosis was computed for the different age, sex and season categories. The prevalence rate of fasciolosis in young sheep $20 \%$ was less than in adults sheep $80 \%$ and the difference were not statistically significant $(P>0.05)$. The prevalence of fasciolosis in two sex groups in the present study was $66.66 \%$, 33.33\% in female and male respectively. The difference in the prevalence was not significant $(p>0.05)$. Seasonal prevalence of ovine fasciolosis the highest prevalence was recorded 33.3\%, 20\%, 16\%, 14.6\%, 9.3\%, and 6.66\%, during the months of in June, November, July, October, September and August respectively. The difference in monthly prevalence was significant $(P<0.05)$.
\end{abstract}

Keywords: Busa; Fasciolosis; Ovine; Prevalence

\section{INTRODUCTION}

Ethiopia possess the largest livestock population in Africa, with an estimated population of 7.8 million of equine, 1 million camels, 47 million cattle, 39.6 chickens, 26.1 million sheep, 21.7 goat (CSA, 2009). Small ruminants play a significant role in maintaining household stability by providing meat, milk, skin and religious roles (Alamyew, and Fletcher, 1995).

Among the small ruminants in Ethiopia, sheep are the dominant livestock, providing up to $63 \%$ of cash income and $23 \%$ the food subsistence value obtained from livestock production. Regardless of the large size of the sheep population in the country and the huge potential therein; the productivity per animal and the contribution of this sub sector to the national economy is relatively low due to multitude of constraining factors from this disease due fasciolosis is considered as one of the major parasitic problem that constrained livestock improvement and production programs in Ethiopia (Zelalem and Fletcher, 1991).

Fasciolosis is a serious parasitic disease mainly affecting cattle, sheep and rarely goat and equines (Urquhart, 1996). Fasciola are the large leaf shaped flukes that are commonly known as liver flukes, the high economic importance of fasciolosis is due to the predilection of the parasite in the liver of the host animals that has diverse metabolic activity and its function that depend up on its ability to perform specific metabolic function (Soulsby, 1998). Ovine fasciolosis was one of the major parasite diseases that inflect an enormous loss to sheep production on through mortality, reduction in weight gain, loss of meat and milk production in working power (Wassie, 1996).

Sheep, acute fasciolosis most often results in sudden death without other apparent clinical abnormality (Radostits et al, 2007). Previous studies conducted in the central highlands of Ethiopia showed the significance and wide distribution of the infection (Bergeon,1968; Scott and Goll, 1977; Erich, 1983). Found that the rate of infection was $90 \%$ in Shoa and Gojam provinces, while (Gemechu and Mamo 
1979) reported an overall prevalence of $63 \%$ in cattle at different regionthe country and estimated the economic loss due to decreased productivity alone to roughly 350 million Ethiopian birr (140 million USD) per annum.

Fasciolosis has a high economic impaction tropical high lands and temperate climatic conditional in Africa and other Asia countries (Ogunrinade, 1980). There are the animal grazes on rangeland grazing postures during the early summer and late winter of the season of the year. In general,there is a high risk in summer (wetter) seasons of the year than winter season, in this seasons there is a high mortality in ovine and loss of productivity such as meats of infested animals by the disease (Wassie ,1996). The objective of the current study is prevalence of ovine fasciolosis was computed for the different three study site, age, sex and season categories. Therefore, the objective of this study was:

$>$ To determine the overall prevalence of ovine fasciolosis and to assess the associated risk factors in the study area.

\section{MATERIALS AND MethodS}

\subsection{Study Area}

The study was conducted from June 2018 up to December 2018 in Dawo Woreda. Dawo Woreda is located in southwest part of Oromia Regional state; which is located $96 \mathrm{~km}$ from Addis Abebaand 51 $\mathrm{km}$ from zone central town. It has an annual average rainfall of $148 \mathrm{~mm}$ and an annual average temperature $17.2^{\circ} \mathrm{c}$. The topography and climatic condition of around Busa and its surrounding is suitable for livestock breeding (Office of Sabeta Veterinary Clinic and Laboratory). This area has a total lives stock population near to 98603 from theseBovine 23,499, Shoat 18500, horses 3609, mule 2115, donkey 13763 and poultry 532579 (DawoWoreda Livestock and Fishery Office) andtarget animals wereincluded in the study.

\subsection{Study Population}

The study animals comprised of indigenous sheep of local breeds belonging to the three purposively selected villages of Busanamely Qarsa Galute, Qarsa Bonbi, and Burqa Gode, and consisting of various ages, sexes and season with regard to the prevalence of ovine fasciolosis.

\subsection{Study Design}

A cross-sectional survey was conducted from June, 2018 up to December 2018 to determine prevalence of ovine fasciolosis in Oromia region, South West Shoa, DawoWoreda Busa town.

\subsection{Sample Size Determination}

A total of 285sheep (100 from Qarsa Galute, 90 from Qarsa Bonbi, 95 from Burqa Gode) were randomly collected and examined by following coprologically examination procedure. The study was conducted on sheep at the field areas from farmers, which bring in Busa Veterinary clinic Since there is no pervious, information on the level of prevalence of ovine fasciolosis was estimated $50 \%$ of expected prevalence and the sample size was determined using the formula (Thrusfield, 1995).

$$
\mathrm{N}=\frac{1.962 \times \mathrm{X} \operatorname{expX}(1-\mathrm{Pexp})}{\mathrm{d}^{2}}=285
$$

$\mathrm{N}=$ number of study population, $\mathrm{Pexp}=$ expected prevalence, $\mathrm{D}=\mathrm{desired}$ precision

\subsection{Fecal Sample Collection and Laboratory Techniques}

In the laboratory coproscopic examination were performed to detect the presence of Fasciola egg, according to standard technique as described by Hasen and Perry (1994). Fresh fecal samples for parasitological examination were collected directly from the rectum by using disposable plastic gloves and placed in clean screw capped universal bottles. Each sample was labeled with date of submission, age, sex, Season and place of origin (Woreda). Sedimentation technique was used a qualitative method for detecting Fasciola.

\subsection{Data Analysis}

The 285 clinical investigations for prevalence was analyzed using statistical package for STATA 7.1. Variation of the prevalence between different groups was analyzed by using chi square (X2) test. The 
A Study on Prevalence of Ovine Fasciolosis in Busa Town, Dawo Woreda, South West Shoa Zone, Oromia Region

associations of fasciola infection rates because of sex, age, site and prevalencewere compared using chi-test or t-test.

\section{RESULTS}

\subsection{Overall Prevalence}

From 285 fecal samples examined from sheep for ovine fasciolosis during the study periods, 150 samples were positive for liver fluke infections with an overall prevalence rate of $52.63 \%$ (Table 1). Difference in prevalence rate was observed among the three study sites from which the samples were collected. Hence, the prevalence rates recorded were 46.6\% in Qarsa Galute 23.3\% in Qarsa Bonbi and 30\% Dhaka Burqa Gode (Table 1). Infection rates on age and sex basis were also compared and as a result, no significant difference in prevalence was observed between the two age groups (Table $3 \& 4)$.

Table1. Overall ovine Fasciolosis prevalence

\begin{tabular}{|l|l|l|}
\hline Result & No. of Animal Examined & Prevalence (\%) \\
\hline Positive & 150 & $52.63 \%$ \\
\hline Negative & 135 & $47.36 \%$ \\
\hline Total & $\mathbf{2 8 5}$ & $\mathbf{1 0 0}$ \\
\hline
\end{tabular}

Table2. Prevalence of ovine fasciolosis the basis of site

\begin{tabular}{|l|l|l|l|}
\hline Site & No. of Animal Examined & No. of positive Sample & Prevalence (\%) \\
\hline QarsaGalute & 100 & 70 & $46.6 \%$ \\
\hline QarsaBonbi & 90 & 35 & $23.3 \%$ \\
\hline BurqaGode & 95 & 45 & $30 \%$ \\
\hline Total & $\mathbf{2 8 5}$ & $\mathbf{1 5 0}$ & $\mathbf{1 0 0}$ \\
\hline
\end{tabular}

Table3. Prevalence of ovine fasciolosis on basis age

Infection rates on age basis were also compared and as a result, no significant difference in prevalence was observed between the two age groups (Table 3).

\begin{tabular}{|l|l|l|l|l|}
\hline Age & $\begin{array}{l}\text { No. of animal } \\
\text { examined }\end{array}$ & No. of positive sample & $\begin{array}{l}\text { No. of Negative } \\
\text { Sample }\end{array}$ & Prevalence (\%) \\
\hline Adult & 200 & 120 & 80 & $80 \%$ \\
\hline Young & 85 & 30 & 55 & $20 \%$ \\
\hline Total & $\mathbf{2 8 5}$ & $\mathbf{1 5 0}$ & $\mathbf{1 3 5}$ & $\mathbf{1 0 0}$ \\
\hline
\end{tabular}

The prevalence rate on the basis of sex also analyzed and the statistical analysis $66.6 \%$ in female and $33.3 \%$ in male showed no significant difference $(\mathrm{P}>0.05)$ (Table-4).

Table4. Prevalence of ovine fasciolosis on basis of sex

\begin{tabular}{|l|l|l|l|l|}
\hline Sex & $\begin{array}{l}\text { No. of Animal } \\
\text { Examined }\end{array}$ & $\begin{array}{l}\text { No. of Positive } \\
\text { Sample }\end{array}$ & $\begin{array}{l}\text { No. of Negative } \\
\text { Sample }\end{array}$ & Prevalence (\%) \\
\hline Female & 180 & 100 & 80 & $66.66 \%$ \\
\hline Male & 105 & 50 & 55 & $33.33 \%$ \\
\hline Total & $\mathbf{2 8 5}$ & $\mathbf{1 5 0}$ & $\mathbf{1 3 5}$ & $\mathbf{1 0 0}$ \\
\hline
\end{tabular}

Table5. Prevalence of fasciolosis at basis of season

\begin{tabular}{|l|l|l|l|l|}
\hline Season & $\begin{array}{l}\text { No. Of animal } \\
\text { examined }\end{array}$ & $\begin{array}{l}\text { Number of } \\
\text { positive sample }\end{array}$ & $\begin{array}{l}\text { No. Of negative } \\
\text { sample }\end{array}$ & Prevalence\% \\
\hline June & 90 & 50 & 40 & $33.3 \%$ \\
\hline July & 40 & 24 & 16 & $16 \%$ \\
\hline August & 20 & 10 & 10 & $6.66 \%$ \\
\hline September & 25 & 14 & 11 & $9.3 \%$ \\
\hline October & 50 & 22 & 28 & $14.6 \%$ \\
\hline November & 60 & 30 & 30 & $20 \%$ \\
\hline Total & $\mathbf{2 8 5}$ & $\mathbf{1 5 0}$ & $\mathbf{1 2 3}$ & $\mathbf{1 0 0 \%}$ \\
\hline
\end{tabular}

\section{DISCUSSION}

The result of the study showed the distribution of 285 ovine examined for Fasciolosis by age. 85 (20\%) ovine examined were young, $200(80 \%)$ were adult. The result of study showed the distribution 
of ovine examined for Fasciolosis by sex, $33.33 \%$ animals were found male and $66.66 \%$ female. The prevalence of fasciolosis was higher in female animals than in male (Table-4), nevertheless it was not significant $(\mathrm{P}>0.05)$.

Younger animals showed higher prevalence than adult ones (Table-3), however, the variation as not statistically significant $(\mathrm{P}>0.05)$. This indicates that both sex and age seems have no impact on the infection rate i.e. both sex \& age groups are equally susceptible to fasciolosis. Similar results that support the present finding were reported by (Aseged, 1990, Mulualem, 1998, Jarso, 2016).

According to statistical analysis of infection rates based onsite, the lowest prevalence rate $(23.3 \%)$ was recorded at SodoLiban, while the highest rate (46.6\%) was observed at Soyoma. These differences in prevalence among the three selected study sites were not statistically significant $(\mathrm{P}>0.05)$ (Table- 2). Similar result that supports the present finding was reported by (Ahmad et al. 2011; Jarso, 2016).

Concerning seasonal prevalence of ovine fasciolosis from highest to lowest prevalence was recorded $33.3 \%, 20 \%, 16 \%, 14.6 \%, 9.3 \%$, and $6.66 \%$, during the months of in June, November, July, October, September and August respectively. The highestprevalence was recorded 33.3\%, 20\% in June and November. The difference in monthly prevalence was significant $(\mathrm{P}<0.05)$. To Shaw (Table -5$)$ this difference may be due to rainy season and the lowest prevalence was recorded in August andSeptember month where the green feed was not available due to dry season of the month. The prevalence of fasciolosis was higher in the wet season of the year. This difference may be due to bionomic factors such as monthly total rainfall, average humidity and temperature similar work was done by Mulualem. (1998). High prevalence rate were recorded in December and January during the study period. Previous studies carried out in Debre Berhan have indicated October/ November as period of maximum infection of sheep with liver flukes (Jarso, 2016).

\section{CONCLUSION AND RECOMMENDATIONS}

The current study showed presence of high prevalence of fasciolosis in sheep However, low prevalence was recorded on sheep three-study site and its surrounding. This suggests that fasciolosis of the major constraints of the health \& productivity of ruminants in the area. As a result, attempts' should be done to minimize the economic losses caused by ovine fasciolosis.

Therefore, based on the above concluding remarks the following points are recommended.

Appropriate intervention should be applied to minimize this high prevalence of fasciolosis in the area by training farmers and extension workers

Laboratory equipment, reagents and chemicals should be available in good quality and quantity to perform confirmatory diagnosis of internal parasites.

The animals should be dewormed on time and take an account on management system.

Further detail study should be made on species composition distribution and economic importance of fasciolosis in the area.

\section{REFERENCES}

Ahmad, O., M. Maryam, M. Mohammad, N. Behrooz and B. Saman, (2011): Liver Distomatosis in cattle, Sheep and goats of Northeastern Iran. Global Veterinarian, 6: 241-246.

Amin, M., Mowafy, L., Marzouk, M., Fayek, S., Mohammad, A., (1992): Fasciolosis in man and animals. Zag. Vet J., 20 (3): 404-411.

Andrews, S.J., (1999): The Life Cycle of Fasciloa Hepatica in Fasciolosis, ed. Dalton, and J.P.CAB publishing: Pp. 1-29.

Asegde, G., (1990): Studies on the ecology of helminth parasites in naturally infected indigenous sheep in Awassa, Southern Ethiopia. Ph.D. Desserrtion. MitGenehmigung des FachbereichesAgrarwissens chasten der Justus-Liebig- Universidad Gieben, Pp.156.

Bergeon, P., (1968): Report to the Government of Ethiopia on a veterinary Parasitology survey, Rome, FAO, Pp. 7.

Blood, D.C., Gay, O.M., Henderson, J.A., (1994): Veterinary Medicine Text Book of Disease of Cattle, Sheep, Horse, Pigs and Goat. 
A Study on Prevalence of Ovine Fasciolosis in Busa Town, Dawo Woreda, South West Shoa Zone, Oromia Region

Bowman, D., (2003): D., Eorgis-Parsitology Veterinary $9^{\text {th }}$ ed. Riode. Junior: Elsevier, Pp. 432-439.

Bowman, D., (2010): D., Eorgis-Parsitology Veterinary, $9^{\text {th }}$ ed. Riode. Junior: Elsevier, Pp. 432-439.

CSA (Central statistical Agency), (2009): Agricultural Survey Report on Livestock, Poultry and Bee hives Population, Private Peasant Holdings. Addis Abeba Ethiopia, Pp.2.

Dunn, A.M., (1978): Veterinary Helminthology $2^{\text {nd }}$ ed., butler and tanner, Itd, L, UK pp. 150-159.

Dusak, A., Onur, M.R., Cicek, M., Firat, U., Ren, T. and Dogra, V.S., (2012): Radiological Imaging Futures of Fasciola Hepatica Infection-A pictorial review. Journal of Clinical Imaging Science 2: Pp.2.

Erich, J., (1983): Investigation on fascioliasis in the Ethiopian highlands around DebreBerhan. Thesis of Master Science, Leiden University.Fufa, A., Loma, A., Bekele, M., Hall H.T (1979): Disease and Parasites of Livestock in the Tropics.

Garcia, H.H., Moro. \& P.L. \&Schantz, P.M., (2007): Zoonotic Helminthes Infection of Humans: Echinococcosis, cysticercosis and fasciolosis. Curr.Opin. Infect. Dis. 20: 489-49.

Grabber, M., Daynes, P., (1974): Molluscs: human and animal vectors of trematodosis in Ethiopia. Review Animal Breeding and Veterinary Medicine of the Tropical Countries, 27:307-322.

Hansen, D., Clery, D., Estuningsh, S., Widjajanti, S., Partoutomo, S. and Spithill, T., (1999): immune responses in Indonesian thin tail and merino sheep during a primary infection. FasciolaGigantica. International Journal for Parasitology, 29:1027-35.

Hansen, I. and Perry, B., (1994): The Epidemiology, Diagnosis and control of Helmet Parasite of ruminants. A hand Book for Research Epidemiology and International Laboratory on Animal Disease (ILARD), Nairobi, Kenya.

Hein, T.V., Dung, T.T. K., Chi, N.H., Dahn, P.H. \& Pham, P.T., (2001): Fasciolosis in Vietnam. South West Asian J. Trop. Med. Public Health, 32:48-50.

Jarso, D., Alemayehu, F., Teka, G., and Tesfaye, A.,(2016): Study on Prevalence of Ovine Fasciolosis in and Around DebreBerhan Sheep Breeding and Forage Multiplication Center, FVM, Addis Ababa University, DebreZeit, Ethiopia, Pp. 30.

Kaufman, J., (1996): Parasitic Infectionof Domestic animals; A diagnostic manual $1^{\text {st }}$ ed Berlin: Birk Hauser Verlege, Pp. 1-29.

Khatoon, S. \& Ali, R., (1978): Fresh Water in Mollusks of Pakistan.BullHydrobiol. J. Res. 1: 518-525

Kitika, J.M., Maingib N; Njeruh, F. Mandombui, J.N., (2002): The Prevalence and Economic Impact due to Bovine Fasciolosis in Kenya. Analysis of abattoir date and erestpoorJournal of Veterinary Research South Africa,69(4): Pp. 256-262.

Malone, J.B., (1997): The Lands Escape Epidemiology of Fasciolosis Geographic determinants of Disease risk. In immunology, Pathobiology and Control of Fasciolosis (ed. J. C. Boray).

Mas-Coma, S., Bargues, M.D. \& Esteban, J.G., (1999b): Human fasciolosis. In fasciolosis (J. P Dalton ed.), $1^{\text {st }}$ ed, CABI publishing, Willing Ford. Pp. 411-434.

Mas-Coma, S., Bargues, M.D. \& Valero, M.A., (2005): Fasciolosis and other Plant-borne trematode Zoonosis. Int. J. Parasitology. 35:1255-1278.

Michael, A., (2005): Infection prevalence of ovine fasciolosis in small-scale irrigation schemes along the upper Awash River Basin Ethiop. Vet J,9(1): 19-27.

Michael, A., Beyene, P., Yilma, J., Don, P., Yosef, S., et al. (2005) Infection prevalence of ovine fasciolosis in small-scale irrigation schemes along the upper Awash River Basin and effects of strategic anthelmintic treatment in selected upstream areas Addis Ababa. The Master of Science in Biology. Addis Ababa University, Ethiopia.

Mufti, S., (2011): An Epidemiological Study of Bovine Fasciolosis in Potohar Region, DVM thesis, department of Zoology, faculty of sciences, Pakistan.

Mulualem, E., (1998): Epidemiology of Bovine Fasciolosis in Woreda as of South Gonder Administrative Zone Bordering Lake Tana: In Ethiopia Veterinary Association, Journal 2(1): 1-13.

Myron, Levine, M., (2000): Fluke infection, in strict land, GT., (ED). Hunters Tropical Medicine and Emerging Infectious Disease, $8^{\text {th }}$ ed. Sounders, Pp. 844-847.

Ogunrinade, A., Ogunrinade, B., (1980): Economic importance of bovine fasciolosis in Nigeria. Animal Health and Production, 12(3): 155-159.

Radostits, O.M., Gay, C.C., Hinchliff, K.W., Constable, P.D., (2007): Veterinary Medicine, A Text Book of the Diseases of cattle, horses, sheep, pigs and goats, $10^{\text {th }}$ ed. London, Saunders Elsevier, Pp. 1576-1580.

Scott, J.M., Goll, and P.H., (1977): The Epidemiology and Anthelmintic control of ovine fasciolosis in the Ethiopiancentral highlands. British Veterinary Journal, 133 (3): 273-280. 
Solomon, W. \&Abebe, W., (2007): Effects of Strategic Anthelminthic Treatment Intervention Bovine Fasciolosis; a study conducted in North-west Ethiopia. Vet, J 11(2): 59-68.

Souls by, M.W., (1982): Helminthes, Arthropods and Protozoa of Domesticated Animals, $7^{\text {th }}$ ed. Bellaire Tindal, London, UK, Pp. 40-52.

Tania, R.M. S., (2012): Genetic Characterization of Portuguese Fasciola Hepatica isolates. Master Degree in Molecular, Genetics and Biomedicine. Institute de Hygiene Medicinal Tropical, Universidad Nova de Lisbon, Pp. 28-32.

Thrusfield, M., (1995): Veterinary Epidemiology, $2^{\text {nd }}$ ed. Oxford, Blackwell Science Ltd, Pp. 180-188.

Urquhart, G.M., Armour, J., Duncan, J.L., Dunn, A.M., Jennings, F.W., (1996): Veterinary Parasitology $2^{\text {nd }}$ ed. Oxford, Longman Scientific and Technical Press, Pp. 100-109.

Wessie, M., (1995): Prevalence of Bovine and Ovine Fasciolosis a Preliminary Survey in Nekemte and its surrounding areas, DVM Thesis, FVM, Addis Ababa University, DebreZeit, Ethiopia, Pp. 30.

Zelalem, A. and I. Fletcher, (1991): Small Ruminant Productivity in the Central Ethiopia Mixed Farming the Livestock Improvement Conference, 13-15 November: 141-7.

Citation: Mukarim Abdurahaman et al."A Study on Prevalence of Ovine Fasciolosis in Busa Town, Dawo Woreda, South West Shoa Zone, Oromia Region" International Journal Of Research Studies In Biosciences (Ijrsb), Vol. 7, no. 3, pp. 1-6, 2019. http://Dx.Doi.org/10.20431/2349-0365.0703001

Copyright: (C) 2019 Authors. This is an open-access article distributed under the terms of the Creative Commons Attribution License, which permits unrestricted use, distribution, and reproduction in any medium, provided the original author and source are credited. 